\title{
Development of 1000 Microsatellite Markers across the Date Palm (Phoenix dactylifera L.) Genome
}

A. Hamwieh ${ }^{1}$, J. Farah ${ }^{2}$, S. Moussally ${ }^{2}$, K. Al-Sham'aa ${ }^{1}$, K. Almer ${ }^{3}$, H. Khierallah ${ }^{4}$, S. Udupa ${ }^{6}$, S. Lababidi ${ }^{1}, J_{\text {.A. Malek }}^{5}$, M. Aaouine ${ }^{1}$ and M. Baum ${ }^{1, a^{\prime}}$

${ }^{1}$ The International Center for Agricultural Research in the Dry Areas (ICARDA), Aleppo, Syria

${ }^{2}$ Faculty of Biotechnology Engineering, Aleppo University, Aleppo, Syria

${ }^{3}$ Plant Tissue Culture Lab, PO Box 1967, Doha, Qatar

${ }_{5}^{4}$ Date Palm Research Unit, College of Agriculture, University of Baghdad, Iraq

${ }^{5}$ Weill Cornell Medical College in Qatar, Doha, Qatar

${ }^{6}$ ICARDA-INRA Cooperative Research Project, International Center for Agricultural Research in the Dry Areas (ICARDA), B.P. 6299, Rabat, Morocco

Keywords: $P$. dactylifera, microsatellite marker, simple sequence repeats, adh gene

\begin{abstract}
Date Palm is a major environmental and economic factor in arid climates in many countries around the world. Microsatellite markers have been proven to be very powerful in plant genome analysis because they are locus-specific, codominant, highly polymorphic and highly reproducible. In date palm only few microsatellite markers have been developed so far. Recently, the Cornell Medical College in Qatar issued a draft assembly of the date palm genome ('Khalas') generated by whole genome shotgun next generation DNA sequencing. In this paper, we analyzed the microsatellite motifs across the date palm genome. The results indicated that the most abundant type of microsatellite repeats are dinucleotide repeats (52442 motifs) followed by trinucleotide ( 28503 motifs) and pentanucleotide repeats (12873 motifs). The frequencies of tetra-nucleotide and hexa-nucleotide repeats were less across the genome (5555 and 5810 motifs, respectively). The most common type of dinucleotide repeat was GA $(48.7 \%)$ followed by AT $(37 \%)$. Out of 28645 trinucleotide repeats, TAA and GAA repeats were the most abundant repeats (28.1 and $27.1 \%)$ respectively. More than 1090 new microsatellite markers could be designed. The primary test for 50 primer pairs revealed that $28(56 \%)$ were functional and 19 (38\%) yielded polymorphic PCR products. We wish that the results of our study will be a starting point for researchers making use of the markers for genetic mapping and diversity analysis of date palm.
\end{abstract}

\section{INTRODUCTION}

Date palm (Phoenix dactylifera L, $2 n=2 x=36$ ), is a dioecious perennial monocotyledon fruit plant from the Arecaceae family. The predicted genome size was estimated to be approximately $250 \mathrm{Mbp}$ (Barakat et al., 1999). The origin of this tree is Iraq, and recently, thousands of cultivars have been reported (Hanachi et al., 1998). Date palms have always been clonally propagated to ensure the identity and uniformity of the cultivars.

Discrimination among closely related cultivars by using morphological traits (including fruit morphology) are often unreliable and extremely difficult, especially because of the influence of environmental conditions (Elhoumaizi et al., 2002). Therefore, the need for using DNA marker technology for DNA fingerprinting has become increasingly important in recent years. Several marker systems have been used to study the genetic diversity of date palm, in brief, randomly amplified polymorphic DNA (RAPD) fingerprints have been used to identify date palm accessions in Algeria (Benkhalifa, 1999), in Morocco (Sedra et al., 1998), in Tunisia (Trifi et al., 2000), in Saudi Arabia (Al-Khalifah and Askari, 2003), and in Egypt (Soliman et al., 2003; Adawy

àm.baum@cgiar.org 
et al., 2006). Amplified fragment length polymorphic (AFLP) markers have been applied to study the polymorphisms of date palm cultivars from Egypt and California (Cao and Chao, 2002; El-Assar et al., 2005; Adawy et al., 2006). Microsatellite or simple sequence repeat (SSR) markers have been used in plant diversity analysis because they are locusspecific, codominant, highly polymorphic and highly reproducible. Microsatellite markers have been developed and used to investigate genetic diversity in $P$. dactylifera (Billotte et al., 2004). They used (GA) microsatellite-enriched library to develop 16 microsatellite markers. More recently, 17 microsatellite loci were developed by constructing two microsatellite enriched libraries of date palm by using $(\mathrm{GA})_{\mathrm{n}}$ and $(\mathrm{GT})_{\mathrm{n}}$ repeats (Akkak et al., 2009). These microsatellite markers have been used to assess the genetic diversity and relationships of date palm varieties in Tunisia (Zehdi et al., 2004), in Sudan (Elshibi and Korpelainen, 2007), in Oman (Al-Ruqaish et al., 2008), and in Qatar (Ahmed and AlQaradawi, 2009). However, for a wider use of microsatellite makers evaluating DNA polymorphisms in date palm tree, the development of hundreds of microsatellite markers would be necessary.

Unlocking the date palm occurred in April 2009, when researchers in the Weill Cornell Medical College in Qatar (WCMC-Q) used the variety named 'Khalas' (one of the most popular varieties of the fruit) to issue an assembly draft of the date palm genome generated by whole genome shotgun next generation DNA sequencing. The available sequence is a start point to apply advanced genomic technologies to a better understanding of date palm genome. The objective of this research was to study the frequency of microsatellite motifs across the date palm genome, and to develop new microsatellite markers.

\section{MATERIAL AND METHODS}

\section{Sequence Analysis}

The multi-fasta file of date palm sequence issued by WCMC-Q was downloaded from this web site address: http://qatar-weill.cornell.edu/research/datepalmGenome/ download.html. The sequence file is named as (PdactyKAssembly1.0.fasta - 329328 KB) and contained 271804 fasta sequence clones.

\section{Isolation of Microsatellites}

The microsatellite motifs were classified as perfect, imperfect, compound perfect, or compound imperfect repeats according to the classification of Weber (1990), modified by Hüttel et al. (1999). A microsatellite is referred as 'simple', if a single type of repeat unit repeats several times (e.g., $(\mathrm{CA})_{\mathrm{n}}$; etc.); a 'compound' microsatellite consists of stretches of more than one type of repeat unit (e.g., (GA) $)_{\mathrm{n}} \cdot(\mathrm{TA})_{\mathrm{k}} ;(\mathrm{GT})_{\mathrm{k}} \cdot(\mathrm{TAA})_{\mathrm{l}} \cdot(\mathrm{TA})_{\mathrm{m}}$, etc.); a 'perfect' microsatellite does not contain mutations or interruptions (e.g., (CA)n; $(\mathrm{TAA})_{\mathrm{k}} ;(\mathrm{CT})_{\mathrm{m}} \cdot(\mathrm{GAA})_{\mathrm{n}}$, etc.); an 'imperfect' microsatellite contains mutations or interruptions (e.g., $(\mathrm{CA})_{\mathrm{n}} \mathrm{CC}(\mathrm{CA})_{\mathrm{m}} ;(\mathrm{TA})_{\mathrm{k}} \mathrm{AA}(\mathrm{TA})_{1} \cdot(\mathrm{GA})_{\mathrm{m}}$, etc.), subscripts $\mathrm{k}, \mathrm{l}, \mathrm{n}$ and $\mathrm{m}$ denote number of times the particular microsatellite motif repeats.

Short script was written by us in Perl software to collect the microsatellite motifs from the assembly draft of the date palm genome and categorize them as di-, tri-, tetra-, penta-, and hexa- nucleotide repeats. The percentage of accepted non-repeated nucleotides within the microsatellite motifs was fixed between $10-20 \%$ and called as error rate. For instance, in the following trinucleotide micosatellite $(\mathrm{TTA})_{3}-\mathrm{CAC}-(\mathrm{TTA})_{3}-$ GAC - $(\text { TTA })_{4}-\mathrm{CCGG}-(\mathrm{TTA})_{3}$, consisted of 50 represent nucleotides, whereas ten $(20 \%)$ nucleotides are not repeated sequence. However, only $10 \%$ of error rate was selected for further analysis in this study.

\section{Plant Material}

A total of 30 well-defined reference Iraqi date palm varieties were collected from two date palm stations belonging to the Ministry of Agriculture in Baghdad, Iraq. These female varieties are: 'Ashrasi', 'Barhi', 'Bream', 'Chipchab', 'Guntar', 'Helawi', 'Jamal 
Al-Dean' and 'Khedrawi'. Total cellular DNA was extracted from young and healthy leaves as described by Rogers and Bendich (1985) with minor modifications. After purification, the obtained DNA was quantified and its integrity checked by using agarose gel electrophoresis $(1 \%)$.

\section{Primer Design and PCR Amplification of Microsatellites}

Primer pairs were designed close to the microsatellite repeats in the flanking regions by using Primer3 v. 0.4.0 web base application available at this site address (http://frodo.wi.mit.edu/primer3/). The expected product size was limited to $200 \mathrm{bp}$, the length of the primers varied between 18 and 23 bases, the melting temperature (Tm) is fixed to be around $60^{\circ} \mathrm{C}$, and all other parameters were kept as default values without change.

The PCR reactions were performed in a total reaction mixture of $20 \mu$ l containing: $50 \mathrm{ng}$ of total cellular DNA $(2 \mu \mathrm{l})$ as template, 1X PCR buffer (Roche, Manheim Germany), $0.2 \mathrm{mM}$ of dNTP PCR mix (Roche), $0.5 \mathrm{U}$ of Taq DNA polymerase (Roche) and $10 \mathrm{pmol}$ of each primers (forward and reverse primers). Amplifications were performed in a Applied Biosystem Thermocycler (Applied Biosystem) with the following conditions: a denaturation step of $5 \mathrm{~min}$ at $95^{\circ} \mathrm{C}$ followed by 35 cycles of $15 \mathrm{~s}$ at $95^{\circ} \mathrm{C}$, $15 \mathrm{~s}$ at $58^{\circ} \mathrm{C}$ and $30 \mathrm{~s}$ at $72^{\circ} \mathrm{C}$, and a final extension step at $72^{\circ} \mathrm{C}$ for $5 \mathrm{~min}$. Amplification products were separated on $8 \%$ polyacrylamide gels stained by ethidium bromide. The DNA banding patterns were visualized on an UV transilluminator and documented by using Gel Documentation System (Alpha Innotech).

\section{RESULTS AND DISCUSSIONS}

\section{Microsatellite Motifs}

The assembly draft of the date palm genome was analyzed and screened for microsatellites motifs using a script in Perl software (supplemented date). The results indicated that the draft sequence of date palm consisted of 321,278,327 bases including 94,386,304 adenine "A", 57,044,647 cytosine "C", 57,187,022 guanine "G", 94,100,785 thymine " $\mathrm{T}$ ", and 18,559,569 unspecified nucleotides "N" (Table 1). Microsatellite motifs varied according to the three error rates $(10,15,20 \%)$, less error rate showed less microsatellite motifs counted (Fig. 1). However, we used a 10\% error rate in this study to increase the efficiency of microsatellite assessment.

Microsatellite motifs were frequently identified across the genome in about 105,183 microsatellite motifs (approximately one microsatellite per 3054.5 bases). Most of the repeats in date palm were of the simple/imperfect type $(55,425$ motifs $)$ comparing to the simple/perfect (48,868 motifs). In contrast, many studies of plant species reported simple/perfect motifs to be the most abundant repeats in Brassica napus L. (Kresovich et al., 1995), in chickpea (Cicer arietinum L.) (Hüttel et al., 1999; Winter et al., 1999), and in lentil (Hamwieh et al., 2009). Among the microsatellite repeats, dinucleotide were the most abundant repeats across the date palm genome (52,442 motifs) followed by trinucleotide repeats $(28,503$ motifs) (Table 1$)$. The most abundant repeat type in date palm genome was AG/TC (25,903 motifs) followed by AT/TA (20,160 motifs) then AC/TG (6,756 motifs). Billotte et al. (2004) developed 16 microsatellite primers from $(\mathrm{GA})_{\mathrm{n}}$ microsatellite-enriched library by using GA. Later, Akkak et al. (2009) developed 17 microsatellite primers from two enriched libraries by using $(\mathrm{GA})_{\mathrm{n}}$ and $(\mathrm{GT})_{\mathrm{n}}$ repeats. Approximately $94.1 \%$ of their microsatellite motifs published were identified by the $(\mathrm{GA})_{\mathrm{n}}$ library. This supports our finding that GA is the predominant repeat across date palm genome. However, the GT repeat is one of the most frequently occurring microsatellites in human and many mammals (Toth et al., 2000). This is also the case in some plant species, such as wheat (Varshney et al., 2000) and Pinus radiata (Smith and Devey, 1994), but this repeat (GT) is comparatively less frequent in other plants (Lagercrantz et al., 1993; Morgante and Olivieri, 1993). However, the dinucliotide repeats varied even within the genome itself between linkage groups or chromosomes. For 
example, among the dinucleotide repeats across Arabidopsis thaliana genome, GT was most abundant in chromosome 1 followed by chromosome 4, 2 and 3 respectively, but this repeat was not found in chromosome 5 (Tamanna and Khan, 2005).

Trinucleotide repeat motifs have also been identified in plant genomes, the most frequently identified are (TAA)n and (GAA)n (Akkaya et al., 1992; Lagercrantz et al., 1993; Morgante and Olivieri, 1993; Winter et al., 1999). In the present study, trinucleotide repeats $(\mathrm{TAA})_{\mathrm{n}}$ and $(\mathrm{GAA})_{\mathrm{n}}$ were recovered in only 14,997 motifs of microsatellite representing $52 \%$ of the 28,645 trinucleotide motifs obtained across the date palm genomic sequence. Nonetheless, the isolation of trinucleotide repeats in date palm is expected to be important since the detection of polymorphisms involving trinucleotide microsatellite motifs may be easier compared with dinucleotide motifs, due to the presence of an extra base pair in the repeat unit (Hearne et al., 1992). Finally, less compound microsatellites were detected across the genome, included 702 dinucleotide motifs and 141 trinucleotide motifs.

\section{Development of Microsatellite Markers}

In total 1091 primer pairs could be designed in the flanking regions of simple/perfect microsatellite motifs. The expected sizes of these primers ranged between 113 and $345 \mathrm{bp}$ with an average of $208 \mathrm{bp}$. Out of these primer combinations, 377 flanked dinucleotide, 352 primer pairs flanked trinucleotide, and 362 primer pairs flanked tetranucleotide repeats. Out of 33 published microsatellite primers only 22 (10 out of 16 microsatellite primers published by Billotte et al., 2004, and 12 out of 17 primers published by Akkak et al., 2009) could be detected in the sequence (Table 3).

To estimate the functional capacity of these primers, 50 primer pairs were tested with 8 Iraqi date palm varieties. The results revealed that 28 primers combinations were functional $(56 \%)$ and $18(36 \%)$ revealed polymorphic alleles (Table 4). If we extrapolate these results we would expect to obtain out of the 1091 primers at least 350 polymorphic microsatellite across the date palm genome. Certainly, these new co-dominant markers will be a starting point for researchers making use of the markers for genetic mapping and diversity analysis of date palm.

It is important to mention that clone number (>PdactyK1.0Scaffold 1817710 length $7070 \mathrm{C}$ ) showed $91 \%$ similarity to the Washingtonia robusta alcohol dehydrogenase $(a d h)$ gene, (reference number on NCBI is: U65972.1). This microsatellite motif can be found under DPALM1091 (in the supplementary file). The adh gene was reported previously as the genetic basis for sex determination in date palm (Rajendran and Al-Mssallem, 2007). They yielded two clear bands of $800 \mathrm{bp}$ and $1000 \mathrm{bp}$ for the female genotypes and a single fragment of approximately $800 \mathrm{bp}$ in male genotypes. In this study, we identified one microsatellite motif $(\mathrm{ATG})_{2}(\mathrm{AT})_{3} \mathrm{C}(\mathrm{ATG})(\mathrm{AT})_{3}$ which is located 158 bases away from the $a d h$ gene. It needs to be tested if derived microsatellite markers could be used to screen for sex.

\section{Literature Cited}

Adawy, S.S., Hussein, E.H.A., Ismail, S.E.M.E.M. and El-Itriby, H.A. 2006. Genomic diversity in date palm (Phoenix dactylifera L.) as revealed by AFLPs in comparison to RAPDs and ISSRs. In: Abstracts of $3^{\text {rd }}$ international date palm conference, Abu Dhabi, United Arab Emirates, 19-21 February.

Ahmed, T.A. and Al-Qaradawi, A. 2009. Molecular phylogeny of Qatari date palm genotypes using simple sequence repeats markers. Biotechnology 8:126-131.

Akkak, A., Scariot, V., Torello Marinoni, D., Boccacci, P., Beltramo, C. and Botta, R. 2009. Development and evaluation of microsatellite markers in Phoenix dactylifera L. and their transferability to other Phoenix species. Biologia Plantarum 53:164-166.

Akkaya, M.S., Bhagwat, A.A. and Cregan, P.B. 1992. Length polymorphisms of simple sequence repeat DNA in soybean. Genetics 132:1131-1139.

Al-Khalifah, N.S. and Askari, E. 2003. Molecular phylogeny of date palm (Phoenix dactylifera L.) cultivars from Saudi Arabia by DNA fingerprinting. Theor. Appl. 
Genet. 107:1266-1270

Al-Ruqaishi, I.A., Davey, M., Alderson, P. and Mayes, S. 2008. Genetic relationships and genotype tracing in date palm(phoenix dactylifera L.) in Oman based on microsatellite markers. Plant Genet. Resour. 61:70-72.

Barakat, A., Han, D.T., Benslimane, A., Rode, A. and Bernardi, G. 1999. The gene distribution in the genomes of pea, tomato and date palm. FEBS Lett. 463:139-42.

Benkhalifa, A. 1999. Gestion de la diversité génétique du palmier dattier en Algérie. Paper presented at the workshop constitution et organisation d'équipes de recherche scientifique dans les domaines de foresterie et des arbres fruitiers, Marrakech, Morocco, 13-15 April.

Billotte, N., Marseilla, N., Brottier, P., Noyer, J.L., Jacquemoud-Collet, J.P., Moreau, C., Couvreur, T., Chevallier, M.H., Pintaud, J.C. and Risterucci, A.M. 2004. Nuclear microsatellite markers for the date palm (Phoenix dactylifera L.): characterization, utility across the genus Phoenix and in other palm genera. Mol. Ecol. Notes 4:256258.

Cao, B.R. and Chao, C.T. 2002. Identification of date cultivars in California using AFLP markers. Hort. Sci. 37:966-968.

El-Assar, A.M., Krueger, R.R., Devanad, P.S. and Chao, C.T. 2005. Genetic analysis of Egyptian date (Phoenix dactylifera L.) accessions using AFLP markers. Genet. Resour. Crop Evol. 52:601-607.

Elhoumaizi, M.A., Saaidi, M., Oihabi, A. and Cilas, C. 2002. Phenotypic diversity of date-palm cultivars (Phoenix dactylifera L.) from Morocco. Genet. Resour. Crop Evol. 49:483-490.

Elshibli, S. and Korpelainen, H. 2007. Microsallite markers reveal high genetic diversity in date palm (phoenix dactylifera L.) germplasm from Sudan. Genetica 134:251-260.

Hamwieh, A., Udupa, S.M., Sarker, A., Jung, C. and Baum, M. 2009. Development of new microsatellite markers and their application in the analysis of genetic diversity in lentils. Breeding Science 59:77-86.

Hanachi, S., Benkhalifa, A., Khirtri, D. and Brac de la Perrière, R.A. 1998. Inventaire Varietal de la Palmeraie Algerienne. [Varietal inventory of the Algerian palms.] CDARS, Anep Rouiba (In French).

Hearne, C.M., Ghosh, S. and Todd, J.A. 1992. Microsatellites for linkage analysis of genetic traits. Trends Genet. 8:287-294.

Hüttel, B., Winter, P., Weising, K., Choumane, W., Weigand, F. and Kahl, G. 1999. Sequence-tagged microsatellite site markers for chickpea (Cicer arietinum L.). Genome 42:210-217.

Kresovich, S., Szewc-McFadden, A.K., Bliek, S.M. and McFerson, J.R. 1995. Abundance and characterization of simple-sequence repeats (SSRs) isolated from a sizefractionated genomic library of Brassica napus L. (rapeseed). Theor. Appl. Genet. 91:206-211.

Lagercrantz, U., Ellegren, H. and Andersson, L. 1993. The abundance of various polymorphic microsatellite motifs differs between plants and vertebrates. Nucleic Acids Res. 21:1111-1115.

Morgante, M. and Olivieri, A.M. 1993. PCR-amplified microsatellites as markers in plant genetics. Plant J. 3:175-182.

Rajendran, P. and Al-Mssallem, I.S. 2007. Genetic basis for sex determination in date palm (phoenix dactylifera L.). p.641-647. In: R. Keshvachandran, P.A. Nazeem, D. Girija, P.S. John and K.V. Peter (eds.), Recent trends in horticultural biotechnology. New India Publishing Agency.

Rogers, S.O. and Bendich, A.J. 1985. Extraction of DNA from milligram amounts of fresh, herbarium and mummified plant tissues. Plant. Mol. Biol. 5:69-76.

Sedra, M.H., Lashermes, P., Trouslot, P., Combes, M. and Hamon, S. 1998. Identification and genetic diversity analysis of date palm (Phoenix dactylifera L.) varieties from Morocco using RAPD markers. Euphytica 103:75-82.

Sibly, R.M., Whittaker, J.C. and Talbot, M. 2001. A maximum likelihood approach to 
fitting equilibrium models of microsatellite evolution. Mol. Biol. Evol. 18:413-417.

Smith, D. and Devey, M.E. 1994. Occurrence and inheritance of microsatellites in Pinus radiata. Genome 37:977-983.

Soliman, S.S., Ali, B.A. and Ahmed, M.M.M. 2003. Genetic comparisons of Egyptian date palm cultivars (Phoenix dactylifera L.) by RAPD-PCR. Afr. J. Biotechnol. 2:8687.

Tamanna, A. and Khan, A.U. 2005. Mapping and analysis of Simple Sequence Repeats in the Arabidopsis thaliana Genome. Bioinformation 1:64-68.

Toth, G., Gaspari, Z. and Jurka, J. 2000. Microsatellites in different eukaryotic genomes: survey and analysis. Genome Res. 10:967-981.

Trifi, M., Rhouma, A. and Marrakchi, M. 2000. Phylogenetic relationships in Tunisian date-palm (Phoenix dactylifera L.) germplasm collection using DNA amplification fingerprinting. Agronomie 20:665-671.

Varshney, R.K., Kumar, A., Balyan, H.S., Roy, J.K., Prasad, M. and Gupta, P.K. 2000. Characterization of microsatellites and development of chromosome specific STMS markers in bread wheat. Plant Mol. Biol. Rep. 18:5-16.

Weber, J.L. 1990. Informativeness of human $(\mathrm{dC}-\mathrm{dA})_{\mathrm{n}}(\mathrm{dG}-\mathrm{dT})_{\mathrm{n}}$ polymorphisms. Genomics 7:524-530.

Winter, P., Pfaff, T., Udupa, S.M., Huettel, B., Sharma, P.C., Sahi, S., Arreguin Espinoza, R., Weigand, F., Muehlbauer, F.J. and Kahl, G. 1999. Characterization and mapping of sequence-tagged microsatellite sites in the chickpea (Cicer arietinum L.) genome. Mol. Gen. Genet. 262:90-101.

Zehdi, S., Sakka, H., Rhouma, A., Salem, A.O.M., Marrakchi, M. and Trifi, M. 2004. Analysis of Tunisian date palm germplasm using simple sequence repeat primers. Afr. J. Biotechnol. 3:215-219.

\section{Tables}

Table 1. The number of the nucleotides and its frequency within the date palm genome.

\begin{tabular}{lcc}
\hline Nucleotide & Count & Frequency \\
\hline Adenine(A) & $94,386,304$ & 0.294 \\
Cytosine(C) & $57,044,647$ & 0.178 \\
Guanine(G) & $57,187,022$ & 0.178 \\
Thymine(T) & $94,100,785$ & 0.293 \\
Unspecific (N) & $18,559,569$ & 0.058 \\
C+G & $114,231,669$ & 0.356 \\
A+T & $188,487,089$ & 0.587 \\
\hline
\end{tabular}


Table 2. Frequency of various types of microsatellite motifs observed across the date palm genome.

\begin{tabular}{|c|c|c|c|c|c|}
\hline & 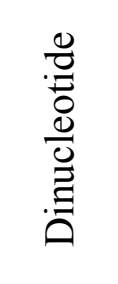 & 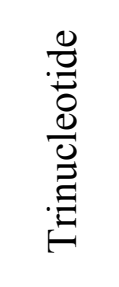 & 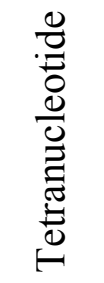 & 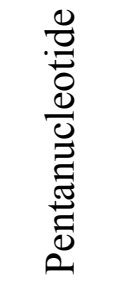 & 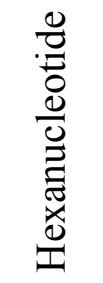 \\
\hline \multirow[t]{2}{*}{ Simple } & 24256 & 13182 & 3729 & 5449 & 2252 \\
\hline & 27484 & 15180 & 1807 & 7409 & 3545 \\
\hline Total & 51740 & 28362 & 5536 & 12858 & 5797 \\
\hline Compound & 702 & 141 & 19 & 15 & 13 \\
\hline Total & 52442 & 28503 & 5555 & 12873 & 5810 \\
\hline
\end{tabular}

Table 3. Date palm genomic clones used by Billotte et al. (2004) and Akkak et al. (2009) to develop microsatellite primers.

\begin{tabular}{|c|c|c|}
\hline Reference & Primes & Clone number \\
\hline \multirow{10}{*}{$\begin{array}{l}\text { Billotte et al. } \\
(2004)\end{array}$} & $\mathrm{mPdClR} 010$ & $>$ PdactyK1.0Scaffold 271028 length 2103 \\
\hline & mPdClR025 & $>$ PdactyK1.0Scaffold 375496 length 3618 \\
\hline & mPdClR032 & $>$ PdactyK1.0Scaffold $952984^{-}$length 2335 \\
\hline & $\mathrm{mPdClR} 050$ & >PdactyK1.0Scaffold_1723771_length_10937 \\
\hline & mPdCIR057 & >PdactyK1.0Scaffold 1698674 length 1883 \\
\hline & $\mathrm{mPdClR} 070$ & >PdactyK1.0Scaffold 961639 length 1935 \\
\hline & mPdClR078 & >PdactyK1.0Scaffold 36821 length $\overline{1} 0487$ \\
\hline & mPdClR085 & $>$ PdactyK1.0Scaffold 1084952 length 3573 \\
\hline & mPdClR090 & >PdactyK1.0Scaffold_830856_length_5891 \\
\hline & mPdClR093 & >PdactyK1.0Scaffold_1742274_length_2028 \\
\hline \multirow{12}{*}{$\begin{array}{l}\text { Akkak et al. } \\
(2009)\end{array}$} & PDCAT10 & $>$ PdactyK1.0Scaffold_1871877_length_11760 \\
\hline & PDCAT11 & >PdactyK1.0Scaffold 332319 length 10772 \\
\hline & PDCAT14 & >PdactyK1.0Scaffold_1406391_length_898 \\
\hline & PDCAT15 & >PdactyK1.0Scaffold_1377333_length_946 \\
\hline & PDCAT17 & $>$ PdactyK1.0Scaffold-1077978-1ength_-376 \\
\hline & PDCAT18 & >PdactyK1.0Scaffold 1165340 length_2957 \\
\hline & PDCAT1 & >PdactyK1.0Scaffold_1498949_length_13938 \\
\hline & PDCAT20 & >PdactyK1.0Scaffold_ 317589_length_3777 \\
\hline & PDCAT21 & >PdactyK1.0Scaffold 836398 length 3971 \\
\hline & PDCAT3 & >PdactyK1.0Scaffold_1661598_length_4767 \\
\hline & PDCAT6 & >PdactyK1.0Scaffold_1657267_length_1165 \\
\hline & PDCAT8 & $>$ PdactyK1.0Scaffold 1541464 length 3258 \\
\hline
\end{tabular}


Table 4. Forward and reverse primer sequences of the primers revealed polymorphic loci in mini core collection of Iraqi date palm varieties.

\begin{tabular}{|c|c|c|c|c|c|}
\hline No & $\begin{array}{l}\text { Primer } \\
\text { Name }\end{array}$ & Forward Primer & Reverse Primer & $\begin{array}{l}\text { Expected } \\
\text { size }\end{array}$ & $\mathrm{Tm}^{\circ}$ \\
\hline 1 & DPALM100 & GCCACTATCACCATTGCTGT & CAATGGAGGTCGTAGTGGTG & 203 & 59 \\
\hline 2 & DPALM103 & TTCCATCCCTGGAGAAAGG & AACCAAGACATCGTCCCAAG & 200 & 60 \\
\hline 3 & DPALM104 & GGAAAGTTTCGGAACATTTTGT & AACCCAACCTAAGCCCTACC & 228 & 59 \\
\hline 4 & DPALM107 & GGAAGGCGTCAAGGTATCTC & ACAACACGGGGAAAGAACAT & 200 & 59 \\
\hline 5 & DPALM110 & TGTCACATTATTTGAGCATAATCCA & ACCCTTTGTTGATGCACCTC & 178 & 60 \\
\hline 6 & DPALM112 & AGCAGGTTCATGGTTTGCTT & AGAACCAGGGAGGATGAGGT & 200 & 60 \\
\hline 7 & DPALM113 & GGTCCCGACGCCTATTTTAT & AGCAAAGTCCACCCCTTTTT & 255 & 60 \\
\hline 8 & DPALM119 & TGCGCTAAATAGTTCCCTTCA & CACATTCACAAGGCCTGCTA & 208 & 60 \\
\hline 9 & DPALM120 & TTCAATTCATCCCACTGCAA & CACCAACATGAGCAAATGGA & 222 & 60 \\
\hline 10 & DPALM121 & CATATGATTGTGATGGGGACA & САCСТCTCCGAGAAAACCAG & 210 & 59 \\
\hline 11 & DPALM123 & GGCAGGTGGATTGTTCTTGT & CAGGGGTATGGAGAGAGAGAGA & 207 & 59 \\
\hline 12 & DPALM125 & TTATGCTGAGGCCAGGTTTT & CATGCTGCAGAACCTGAAGA & 191 & 60 \\
\hline 13 & DPALM132 & TCAGCTCAAAGCACACAACA & CCGGAGATTTTGTTTCGATG & 226 & 60 \\
\hline 14 & DPALM133 & CAGATGGGATCGTTTTACCTG & CCGTATCGGGAGAGAGAGAG & 197 & 59 \\
\hline 15 & DPALM139 & TCTCGATCTCGACCTTGGTT & CGGATCCGGTTCTCTCATTA & 202 & 60 \\
\hline 16 & DPALM141 & CATTGCTCAGAAGCATCCAA & СТCTCССТCССТCTCGTTCT & 212 & 60 \\
\hline 17 & DPALM142 & CAATGGACCACCAAAATCAA & CTCTCCGAGAAAACCAGGTC & 179 & 59 \\
\hline 18 & DPALM144 & ACACACACACACACGCGAAT & CTTGCAGCCATTTAGGCAAC & 187 & 61 \\
\hline 19 & DPALM146 & ATGATTGAGAGGCAGGCAAA & GACAAGAGGGAAGGGGAGAG & 198 & 60 \\
\hline
\end{tabular}




\section{Figures}

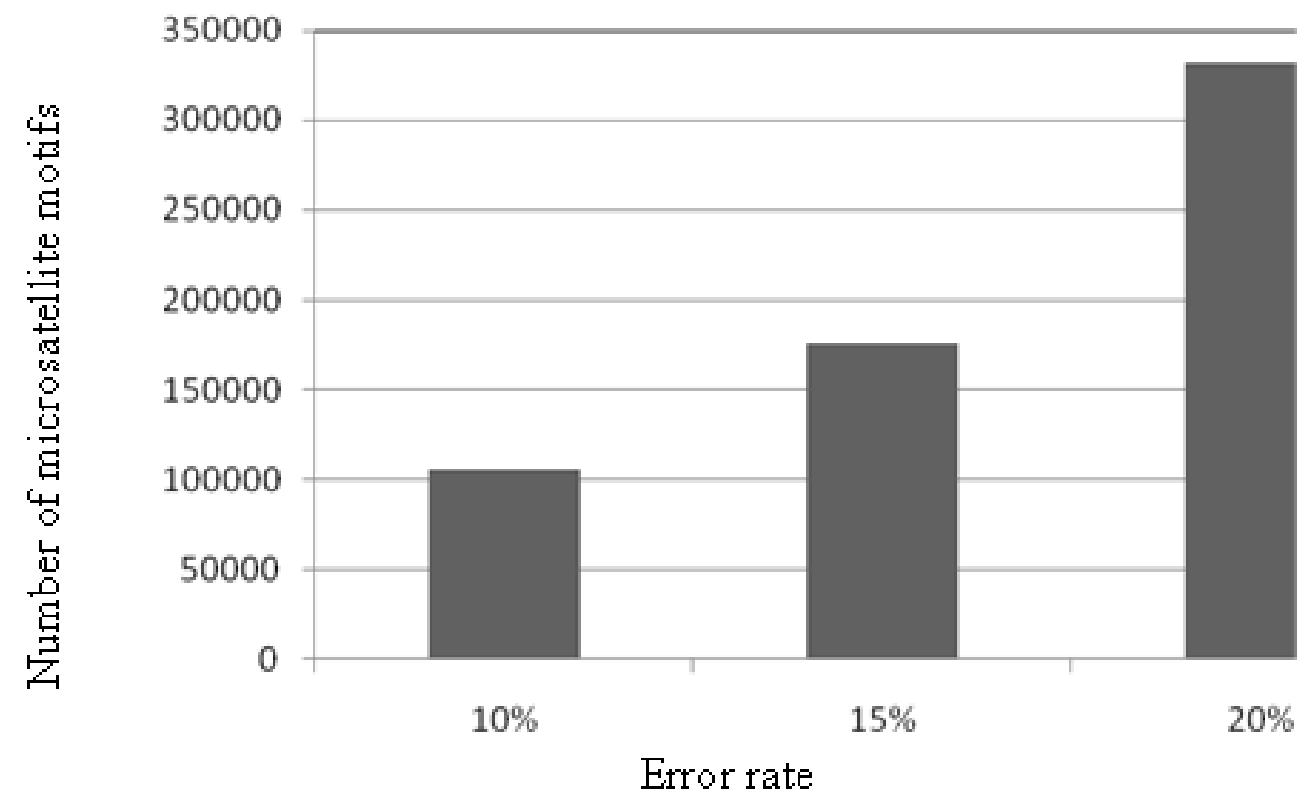

Fig. 1. Number of total microsatellite markers counted according to the different error rates (error rate: non-repeated nucleotides within the microsatellite motif). The figure shows that if more error in the microsatellite sequence is accepted then more microsatellite motifs could be counted. 
